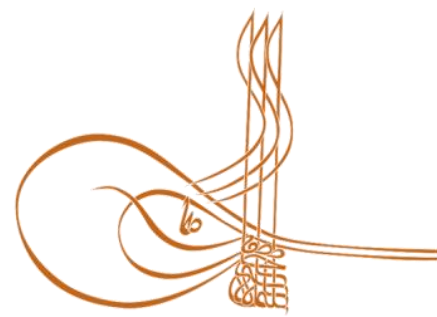

www.turkishstudies.net/economy
Turkish Studies - Economics, Finance, Politics

eISSN: $2667-5625$

Research Article / Araștırma Makalesi

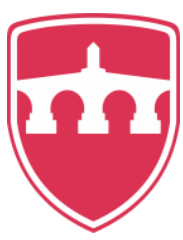

INTERNATIONAL BALKAN

UNIVERSITY

Sponsored by IBU

\title{
Çok Kriterli Karar Verme Yöntemleriyle Finansal Performans Değerlendirme: Ulaştırma Alanında Bir Uygulama
}

\author{
Financial Performance Evaluation By Multi-Criteria Decision Making Methods: An \\ Implimentation in The Field of Transportation
}

\author{
Mehmet Orhan ${ }^{*}-$ Hakan Altın ${ }^{* *}$ - Mehmet Aytekin ${ }^{* * *}$
}

\begin{abstract}
The evaluation of business enterprises' performance is of great importance in order to maintain its existence and continue their activities in the future. One of the most important performance indicators in businesses is financial performance. The aim of this study is to evaluate the financial performance of " Istanbul Bus Companies Trade Inc. " (Otobüs AS/ Bus Inc.) which has been active in the field of public transportation in Istanbul since 2007. For this purpose, firstly, the literature was searched to determine the variables used in the evaluation of financial performance by multi-criteria decision making methods. As a result of literature review, widely used criteria for evaluating the financial performance of firms have emerged and used in analysis. These criteria are "current ratio", "liquidity ratio / acid test ratio", "cash ratio", "asset turnover rate", "accounts receivables turnover rate", "equity turnover rate = net sales / equity", "total debt ratio ", debt / equity ratio ", "short term debt / total asset ratio ", "short term debt / total debt ratio ", " equity / total assets ", " net profit / net sales ", return on assets ratio ", and" return on equity ratio". CRITIC and TOPSIS methods were used in the analysis with 2011-2018 era data. The importance degree (weights) of the criteria used in the analyzes was determined by using the CRITIC method, which allows objective determination. As a result of the analyzes performed by the TOPSIS method by using these criterion weights obtained, Bus Inc.`s financial performance based rankings have been made according to years. According to the CRITIC-weighted TOPSIS method, Bus Inc. has the highest financial performance in 2014.
\end{abstract}

\footnotetext{
* Dr., Gelir İdaresi Başkanlığı

Phd, Revenue Administration

ORCID 0000-0003-1160-0258

mehmetorhan01@gmail.com

** Doç Dr., Aksaray Üniversitesi, İ̈BF, İşletme Bölümü

Assoc. Prof., Aksaray University, FEAS, Department of Business Administration

ORCID 0000-0002-0012-0016

hakanaltinasu@hotmail.com

**** Doç.Dr., Gaziantep Üniversitesi, İ̈BF, İşletme Bölümü

Assoc. Prof., Gaziantep University, FEAS, Department of Business Administration

ORCID 0000-0001-5464-0677

aytekin@gantep.edu.tr

Cite as/ Atıf: Orhan, M., Altın, H., Aytekin, M. (2020). Çok kriterli karar verme yöntemleriyle finansal performans

değerlendirme: ulaştırma alanında bir uygulama, Turkish Studies - Economy, 15(1), 395-410.

https://dx.doi.org/10.29228/TurkishStudies.40149

Received/Geliş: 12 December/Aralık 2019

Accepted/Kabul: $25 \mathrm{March} / \mathrm{Mart} 2020$

Copyright $($ INTAC LTD, Turkey

Checked by plagiarism software

Published/Yayın: 30 March/Mart 2020

CC BY-NC 4.0
} 
Structured Abstract: The survival and growth of businesses in today's conditions; it is about their ability to cope with their competitors, in other words, their capacity to compete. Determining the competitive capacity of businesses reliably depends on measuring and analyzing the financial performance of these enterprises. In addition, it is of great importance to evaluate the financial performance of the companies at regular intervals in order to carry out decision-making, planning and supervision activities effectively, efficiently and healthily. Therefore, one of the most important responsibilities of business managers is to evaluate and analyze the financial performance of businesses. In order for these processes to be carried out successfully, it is necessary to know well which data will best demonstrate the performances of the companies, how they can be obtained and how to evaluate these data. According to the results obtained after the measurement and evaluation of these data, if the business performance is not acceptable, taking measures to achieve a good performance level is one of the important responsibilities of decision-makers (Acar, 2003: 21-22).

The aim of this study is to evaluate the financial performance of " Istanbul Bus Companies Trade Inc. " (Otobüs AŞ/ Bus Inc.), which has been operating in Istanbul in the field of public transport since 2007. In this context, the study was carried out using the financial data of Otobüs AŞ between 2011-2018. Otobüs AŞ was established in 2007 to meet the public transportation needs of Istanbulites by planning the vehicles and service types that will meet not only today's but also the public transportation needs of the city, using the high technology solutions required by modern urbanism. Otobüs AŞ is an enterprise that aims to provide appropriate public transportation services in Istanbul, to maintain sustainable development principles while providing this service, to provide the highest quality service to the public and to provide an economic vitality by developing relevant/various social responsibility policies. Evaluation of financial performance is of great importance in order to achieve these goals.

In this study; CRITIC and TOPSIS method, which are multi-criteria decision-making methods, were used. Multi-criteria decision-making methods (CRITIC, TOPSIS, etc.) based on quantitative data that can be applied in different sectors and areas. Also, Multi-criteria decision-making methods are frequently used in financial literature due to the convenience it provides to individuals, investors, decision-makers, and managers in solving decision-making problems (Ege and Yaman 2018). In this context, a literature review was conducted to determine the variables used in the evaluation of financial performance by multi-criteria decision-making methods. As a result of the literature review, commonly used criteria were determined to evaluate the financial performance of companies and were used in the analysis.

The criteria weights used in financial performance evaluation in this study are; It was determined by using the CRITIC method, which allows determining criteria weights objectively. The ranking of the criteria determined according to the criteria weights ranking determined by CRITIC method, from the most important to the least, the equity turnover rate, equity / total assets, net profit / net sales, short-term debt / total debt ratio, rate of receivable turnover rate, asset turnover rate, assets profitability ratio, total debt ratio, liquidity ratio / acid test ratio, current ratio, equity profitability rate, cash ratio, debt/equity ratio and short term debt / total asset ratio. Financial performance ranking by years was analyzed using the TOPSIS method. As a result of the analyses performed using the CRITIC-weighted TOPSIS method; the financial performance of Otobüs AŞ based on years; It was realized as 2015, 2013, 2012, 2018, 2016, 2011, 2017 and 2014. According to this result, Istanbul Bus Companies Trading Inc. while it had the highest financial performance in 2015, had the worst financial performance in 2014. Within the framework of the results obtained in this study, managers; By analyzing the factors that ensure the financial performance to be high in 2015 or what the differences are compared to other years, and within this framework, strategies can be developed to increase the performance of the business in the coming years. With a reverse perspective, similar evaluations can be made on why performance was low in 2014, necessary measures can be taken in this direction and they can work to correct factors that negatively affect performance.

The criteria weights used in this study were determined objectively with the CRITIC method. Different results can be obtained if methods that allow different evaluation is used in future studies. The TOPSIS method was used while making financial performance evaluation. Different results can be obtained if different multi-criteria decision-making methods (VIKOR EDAS, ARAS, etc ) are used in future studies.

Keywords: Transportation, Financial Performance, CRITIC, TOPSIS. 
Öz: İşletmelerin performanslarının değerlendirilmesi, işletmelerin varlığını sürdürmek ve gelecekte faaliyetlerine devam etmek için büyük önem taşımaktadır. İşletmelerdeki en önemli performans göstergelerinden biri finansal performanstır. Bu çalışmanın amacı 2007 yılından itibaren İstanbul'da şehir içi toplu taşıma alanında faaliyet göstermekte olan "İstanbul Otobüs İşletmeleri Ticaret Anonim Şirketi'nin" (Otobüs AŞ) finansal performansını değerlendirmektir. Bu amaçla öncelikle çok kriterli karar verme yöntemleriyle finansal performans değerlendirilmelerinde kullanılan değişkenlerin belirlenmesi amacıyla literatür taraması yapılmıştır. Literatür taraması sonucunda firmaların finansal performansının değerlendirilmesinde yaygın kullanılan kriterler belirmiş ve analizlerde kullanılmıştır. Bu kriterler "cari oran”, "likidite oranı/asit testi oranı", "nakit oran”, “ aktif devir hızı”, “ alacak devir hızı oranı”, “öz kaynak devir hızı=net satışlar/ öz kaynak”, "toplam borç oranı”, "borç/öz kaynak oranı”, " kısa vadeli borç/toplam aktif oranı”, "kısa vadeli borç/toplam borç oranı”, “öz kaynaklar/toplam varlıklar”, "net kar/net satışlar”, "aktifler karlılığı oranı”, ve “öz kaynak karlılığı oranı”dır. 2011-2018 dönemi verileri ile yapılan analizde CRITIC ve TOPSIS yöntemleri kullanılmıştır. Analizlerde kullanılan kriterlerin önem derecelerinin objektif olarak belirlenebilmesine olanak sağlayan CRITIC yöntemiyle belirlenmiştir. Elde edilen bu kriter ağırlıkları kullanılarak TOPSIS yöntemiyle yapılan analizler sonucunda Otobüs AŞ’nin yıllara göre finansal performans bazlı sıralamaları yapılmıştır. Otobüs AŞ'nin CRITIC ağırlıklı TOPSIS yöntemine göre 2014 yılında en yüksek finansal performansa sahip olduğu tespit edilmiştir.

Anahtar Kelimeler: Ulaştırma, Finansal Performans, CRITIC, TOPSİS.

\section{Giriş}

İşletme performansının değerlendirilmesi, işletmedeki karar vericilerin, doğru ve etkin kararlar alabilmeleri ve böylelikle işletmenin başarısının artırabilmesi, amaç ve hedeflerini gerçekleştirebilmesi için büyük önem arz etmektedir (Bayyurt, 2011:578). İşletme performans1 değerlendirilmesinde en çok başvurulan göstergelerden birisi finansal performansın değerlendirilmesidir (Ayçin, 2019).

Günümüz koşullarında işletmelerin varlığını sürdürebilmesi ve büyümesi; rakipleriyle başa çıabilme yetenekleriyle, başka bir ifadeyle rekabet edebilme kapasitesiyle ilgilidir. İşletmelerin rekabet edebilme kapasitelerinin güvenilir olarak belirlenebilmesi de söz konusu işletmelerin finansal performanslarının ölçülmesine ve analiz edilmesine bağlıdır (Acar, 2003:21). Ayrıca işletmelerde karar verme, planlama ve denetim faaliyetlerinin etkin, verimli ve sağl1klı şekilde gerçekleştirilebilmesi için belli aralıklarla işletmelerin finansal performanslarının değerlendirilmesi büyük önem arz etmektedir. Dolayısıyla işletme yöneticilerinin en önemli sorumluluklarından birisi, işletmelerin finansal performanslarının değerlendirilmesi ve analiz edilmesidir. Bu süreçlerin başarıyla gerçekleştirilebilmesi için işletmelerin performanslarını en iyi şekilde ortaya koyacak verilerin hangileri olduğu, nasıl elde edilebileceği ve elde edilen bu verilerin değerlendirilmesinin nasıl yapılacağının iyi bilinmesi gerekmektedir. Bu verilerin ölçüm ve değerlendirilmesinden sonra da elde edilen sonuçlara göre, eğer işletmenin performansı kabul edilebilir düzeyde değilse, iyi bir performans düzeyine ulaşmayı sağlayacak tedbirlerin alınması, yöneticilerin önemli sorumluluklarından birisidir (Acar, 2003:21-22)

Bu çalışmanın amacı; 2007 yılından itibaren İstanbul'da şehir içi toplu taşıma alanında faaliyet göstermekte olan "İstanbul Otobüs İşletmeleri Ticaret Anonim Şirketi'nin" (Otobüs AŞ) 2011-2018 yılları arasındaki finansal performansını değerlendirmektir. $\mathrm{Bu}$ amaçla işletmelerin finansal performansını değerlendirmesine yönelik yapılan literatür taraması sonucunda, finansal performansını değerlendirmesin de yaygın olarak kullanılan kriterlerin; "cari oran", "likidite oranı/asit testi oranı", "nakit oran", "aktif devir hızı", "alacak devir hızı oranı", "öz kaynak devir hızı=net satışlar/öz kaynak", "toplam borç oranı", "borç/öz kaynak oranı", "kısa vadeli borç/toplam aktif oranı", "kısa vadeli borç/toplam borç oranı", "öz kaynaklar/toplam varlıklar", "net kar/net satışlar", "aktifler karlılığ1 oranı", ve "öz kaynak karlılığı oranı" olduğu belirlenmiştir. Belirlenen bu kriterler analizlerde kıyaslama değişkeni olarak belirlenmiştir. 
Otobüs AŞ’nin finansal performansını değerlendirmesinde kullanılan kriterlere ilişkin veriler kamuoyuna açık biçimde sunulan, işletmenin kurumsal web sayfasında yer alan dokumanlar kısmının mali tablolar bölümünden (http://www.otobus.istanbul) elde edilmiştir. Çalışmanın analiz kısmında işletmelerin finansal performansını değerlendirmesine kullanılan kriterlerin önem derecelerinin objektif olarak belirlenebilmesine olanak sağlayan CRITIC yöntemleriyle belirlenmiştir. Elde edilen kriter ağırlıkları kullanılarak TOPSIS yöntemiyle yapılan analizler sonucunda Otobüs AŞ'nin yıllara göre finansal performans bazlı sıralamaları yapılmıştır.

\section{Litaratür Taraması}

Litaratürde çok kriterli karar verme yöntemleriyle yapılmış birçok çalışma bulunmaktadır (Rençber, 2019: 69-70). Bazı çalışmalar Tablo 1.'de sunulmuştur.

Tablo 1: Litaratürde Çok Kriterli Karar Verme Yöntemleriyle Yapılmış Çalışmalar

\begin{tabular}{|c|c|c|c|c|}
\hline Yazarlar & Örneklem ve Amaç & Dönem & Yöntem & Bulgular \\
\hline $\begin{array}{l}\text { Apan ve Öztel } \\
(2020)\end{array}$ & $\begin{array}{l}\text { Yatırım ortaklıklarının } \\
\text { finansal performans } \\
\text { kıyaslanması }\end{array}$ & $\begin{array}{l}2012- \\
2016\end{array}$ & $\begin{array}{c}\text { CRİTIC } \\
\text { PROMETHEE }\end{array}$ & $\begin{array}{l}\text { Başarı ortalamalarına göre GOZDE en } \\
\text { başarılı işletme olurken, VERTU en kötü } \\
\text { performansı gösteren işletmedir }\end{array}$ \\
\hline $\begin{array}{c}\text { Tufan ve Kılıç } \\
\text { (2019) }\end{array}$ & $\begin{array}{c}\text { BIST'te işlem gören lojistik } \\
\text { hizmet sağlayıcı işletmelerin } \\
\text { finansal performanslarının } \\
\text { kıyaslanması }\end{array}$ & $\begin{array}{l}2014- \\
2017\end{array}$ & $\begin{array}{l}\text { TOPSIS ve } \\
\text { VIKOR }\end{array}$ & $\begin{array}{c}\text { Finansal performansı yüksek olan işletmeler } \\
\text { analiz yöntemine göre farkl1lı gösterirken } \\
\text { her iki yönteme göre de finansal performans1 } \\
\text { düşük olan işletmelerde benzerlik söz konusu } \\
\text { olmuştur }\end{array}$ \\
\hline Apan vd. (2019) & $\begin{array}{c}\text { Bankaların finansal } \\
\text { performans kıyaslanması }\end{array}$ & $\begin{array}{l}2002- \\
2016\end{array}$ & $\begin{array}{l}\text { Entropi } \\
\text { CAMELS }\end{array}$ & $\begin{array}{l}\text { Kamu sermayeli mevduat bankalarının daha } \\
\text { iyi finansal performans göstermektedir. }\end{array}$ \\
\hline Akbulut (2019) & $\begin{array}{l}\text { İş Bankası'nın } \\
\text { Performansının Analizi }\end{array}$ & $\begin{array}{l}2009- \\
2018\end{array}$ & $\begin{array}{l}\text { CRITIC ve } \\
\text { EDAS }\end{array}$ & $\begin{array}{l}\text { Finansal performansın en iyi olduğu y1l } 2009 \\
\text { olmasına karşın; en kötü olan yıl 2018'dir. }\end{array}$ \\
\hline $\begin{array}{l}\text { Akyüz vd. } \\
\text { (2019) }\end{array}$ & \begin{tabular}{|} 
Artvin ilinde faaliyet \\
gösteren orman ürünleri \\
işletmelerinin finansal \\
performansının kıyaslanması
\end{tabular} & $\begin{array}{l}2014- \\
2017\end{array}$ & $\begin{array}{l}\text { TOPSIS ve } \\
\text { ENTROPİ }\end{array}$ & $\begin{array}{c}\text { Finansal performans bakımından genel olarak } \\
\text { "E" işletmesinin en iyi finansal performans } \\
\text { sergilediği, en kötü finansal performans } \\
\text { gösteren işletmelerin yıllara göre değişiklik } \\
\text { gösterdiği bulunmuştur. }\end{array}$ \\
\hline Ayçin (2019) & $\begin{array}{c}\text { Borsa İstanbul menkul } \\
\text { k1ymet yatırım ortaklıkları } \\
\text { endeksine (XYORT) kote } \\
\text { firmaların finansal } \\
\text { performansının kıyaslanması }\end{array}$ & 2018 & $\begin{array}{l}\text { ENTROPİ ve } \\
\text { GIA }\end{array}$ & $\begin{array}{l}\text { En iyi finansal performans gösteren firmanın } \\
\text { İş Yatırım Ortaklığı olduğu belirlenmiştir. İş } \\
\text { Yatırım Ortaklığını ise sırasıyla, Atlas } \\
\text { Menkul Kıymetler Yatırım Ortaklığı ve Oyak } \\
\text { Yatırım Ortaklığı takip etmiştir. }\end{array}$ \\
\hline Aydın (2019) & $\begin{array}{l}\text { Türk sigorta sektöründe } \\
\text { hayat- emeklilik şirketleri } \\
\text { performans kıyaslaması }\end{array}$ & $\begin{array}{l}2015- \\
2017\end{array}$ & $\begin{array}{l}\text { CRITIC ve } \\
\text { TOPSIS }\end{array}$ & $\begin{array}{c}\text { Hayat/emeklilik şirketlerinin finansal açıdan } \\
\text { başarısının en yüksek olduğu yılın } 2015 \\
\text { olduğu tespit edilmiştir. }\end{array}$ \\
\hline Orhan (2019) & $\begin{array}{l}\text { Türkiye ile Avrupa birliği } \\
\text { ülkelerinin lojistik } \\
\text { performans kıaslaması }\end{array}$ & 2018 & Entropi ve EDAS & $\begin{array}{l}\text { Lojistik performans indeksine göre yapılan } \\
\text { analiz sonucunda } 22 \text { sırada yer alımıştır }\end{array}$ \\
\hline $\begin{array}{l}\text { Apan ve Öztel } \\
\text { (2018) }\end{array}$ & $\begin{array}{l}\text { İmalat sektöründeki } \\
\text { işletmelerin finansal } \\
\text { performans kıyaslaması }\end{array}$ & $\begin{array}{l}2004- \\
2014\end{array}$ & $\begin{array}{l}\text { PROMETHEEE } \\
\text { Entropi, CRITIC, } \\
\text { Standart Sapma }\end{array}$ & $\begin{array}{c}\text { Farklı ağırlıklandırma yönteminin } \\
\text { kullanılması farklı sonuçlar elde edilmesine } \\
\text { yol açıştır }\end{array}$ \\
\hline $\begin{array}{l}\text { Rençber ve Avc1 } \\
\text { (2018) }\end{array}$ & $\begin{array}{l}\text { Bankaların sermaye } \\
\text { yeterlilikleri açısından } \\
\text { karşılaştırılması }\end{array}$ & $\begin{array}{l}2012- \\
2017\end{array}$ & WASPAS & $\begin{array}{l}\text { Sermaye yeterlilikleri açısından; Kalkınma, } \\
\text { Albaraka Turk ve TSKB bankaları en iyi; } \\
\text { Finansbank, Denizbank ve QNB'nin ise } \\
\text { düşük düzeyde olduğu sonuca ulaşılmıştır. }\end{array}$ \\
\hline $\begin{array}{l}\text { Kiracı ve Bakır } \\
\text { (2019) }\end{array}$ & $\begin{array}{c}13 \text { havayolu şirketinin } \\
\text { performansının kıyaslanması }\end{array}$ & $\begin{array}{l}2005- \\
2012\end{array}$ & $\begin{array}{l}\text { CRITIC ve } \\
\text { EDAS }\end{array}$ & $\begin{array}{l}2010 \text { yılı, finans krizinin olumsuz etkilerinin } \\
\text { en fazla hissedildiği yıl; UAL havayolu } \\
\text { firması hem küresel krizden önce hem de } \\
\text { sonra finansal başarısı en yüksek firmadır. }\end{array}$ \\
\hline
\end{tabular}




\begin{tabular}{|c|c|c|c|c|}
\hline Ünlü vd. (2016) & $\begin{array}{l}\text { BİST-30 Endeksine kayıtlı } \\
22 \text { firmanın finansal } \\
\text { performans kıyaslaması }\end{array}$ & 2014 & $\begin{array}{l}\text { CRITIC ve } \\
\text { TOPSIS }\end{array}$ & \begin{tabular}{|} 
CRITIC yöntemine göre en önemli kriter \\
nakit katma değer kriteridir. TOPSIS \\
yöntemiyle performans sıralamasına göre en \\
başarılı şirket Şişecam, en başarısız ise \\
THY'dır.
\end{tabular} \\
\hline $\begin{array}{l}\text { Akgün ve Temür } \\
\text { (2016) }\end{array}$ & $\begin{array}{l}\text { BIST'te işlem gören iki hava } \\
\text { taşımacılık firmasının } \\
\text { finansal performansının } \\
\text { kıyaslanması }\end{array}$ & $\begin{array}{l}2010- \\
2015\end{array}$ & TOPSIS & $\begin{array}{c}\text { En yüksek finansal performans göstergesinin } \\
2012 \text { yılında THY'ye, ikinci ve üçüncü sırada } \\
\text { ise } 2014 \text { ve } 2013 \text { ylllarında Pegasus'tur. }\end{array}$ \\
\hline Kıngır vd., 2016 & $\begin{array}{l}\text { Çalışanların iş davranışı } \\
\text { performansının ölçülmesi }\end{array}$ & - & TOPSIS & $\begin{array}{l}\text { TOPSİS yöntemiyle, iş davranışları } \\
\text { performansının ölçülmesi, nitel çabaların } \\
\text { nicel hale getirilerek ölçülmesini } \\
\text { sağlamaktadır. }\end{array}$ \\
\hline $\begin{array}{c}\text { Akbulut ve } \\
\text { Rençber (2015) }\end{array}$ & $\begin{array}{l}\text { BIST'te işlem gören } 32 \\
\text { işletmenin finansal } \\
\text { performans kıyaslanması }\end{array}$ & $\begin{array}{l}2010- \\
2012\end{array}$ & TOPSIS & $\begin{array}{l}\text { İşletmelerin finansal performansları borsa } \\
\text { ileperformansları arasında istatistiki ilişki } \\
\text { bulunmadığı sonucuna ulaşılmışıtır. }\end{array}$ \\
\hline $\begin{array}{c}\text { Bağc1 ve } \\
\text { Rençber (2014). }\end{array}$ & $\begin{array}{c}\text { Özel bankalar ile Kamu } \\
\text { bankaları arasında kârlılık } \\
\text { performansı karşılaştırmasını } \\
\text { yapmak }\end{array}$ & $\begin{array}{l}2006- \\
2012\end{array}$ & PROMETHEE & $\begin{array}{c}\text { Çalışmada kamu bankaları arasında en kârlı } \\
\text { bankanın Halk Bankası, özel bankalarda ise } \\
\text { Denizbank, tüm bankalar içeriside; kamu } \\
\text { bankalarının daha kârlı ve Halk } \\
\text { Bankası'nında en kârlı banka olduğu tespit } \\
\text { edilmiştir. }\end{array}$ \\
\hline Ergül (2014) & $\begin{array}{c}\text { Borsa İstanbul'a kote turizm } \\
\text { sektöründe yer alan yedi } \\
\text { firmanın finansal } \\
\text { performansının kıyaslanması }\end{array}$ & $\begin{array}{c}2005- \\
2012\end{array}$ & $\begin{array}{l}\text { TOPSIS ve } \\
\text { ELECTRE }\end{array}$ & $\begin{array}{c}\text { En iyi finansal performansa sahip firmalar } \\
\text { 2005, 2006, 2011, 2012'de MAALT; 2007, } \\
\text { 2010'da NETTUR; 2008, 2009'da PKENT } \\
\text { olmuştur. En kötü finansal performansa sahip } \\
\text { firmalar ise 2005, 2006, 2007, 2008 } \\
\text { NETTUR ve METUR; 2009, 2010 y1llarında } \\
\text { FVORI; 2011 yılında METUR; } 2012 \text { yılında } \\
\text { AYCES olmuştur. }\end{array}$ \\
\hline $\begin{array}{l}\text { Tayyar vd. } \\
\text { (2014) }\end{array}$ & $\begin{array}{c}\text { BIST'de bilişim ve teknoloji } \\
\text { sektöründeki işletmelerin } \\
\text { finansal performanslarının } \\
\text { değerlendirilmesi }\end{array}$ & $\begin{array}{l}2005- \\
2011\end{array}$ & AHP ve GRA & \begin{tabular}{|c|} 
En önemli kriterin karlılık oranları olduğu ve \\
en yüksek finansal performansa sahip \\
işletmenin Link Bilgisayar A.Ş. olduğu tespit \\
edilmiştir.
\end{tabular} \\
\hline Ege vd. (2013) & $\begin{array}{c}\text { Kurumsal yönetim } \\
\text { endeksinde bulunan seçilmiş } \\
\text { firmaların finansal } \\
\text { performansının kıyaslanması }\end{array}$ & $\begin{array}{l}2009- \\
2011\end{array}$ & TOPSIS & $\begin{array}{c}\text { Şirketlerin finansal performanslarının } \\
\text { kurumsal yönetim notları ile pozitif yönde } \\
\text { hareket etmediği ve şirketlerin kurumsal } \\
\text { yönetim kalitelerinin finansal } \\
\text { performanslarına tam olarak yansımadığı } \\
\text { tespit edilmiştir. }\end{array}$ \\
\hline Bulgurcu (2012) & $\begin{array}{c}\text { BIST'de işlem gören13 } \\
\text { teknoloji şirketinin finansal } \\
\text { performansının kıyaslanması }\end{array}$ & $\begin{array}{l}2009- \\
2011\end{array}$ & TOPSIS & $\begin{array}{c}\text { Elde edilen bulgular, TOPSIS skorları ile } \\
\text { şrket piyasa değeri arasındaki ilişkinin tutarlı } \\
\text { olmadığını göstermektedir. }\end{array}$ \\
\hline $\begin{array}{c}\text { Dinçer ve } \\
\text { Görener (2011) }\end{array}$ & $\begin{array}{c}\text { Mevduat bankalarının } \\
\text { performans değerlendirmesi }\end{array}$ & 2008 & $\begin{array}{c}\text { AHP, TOPSIS ve } \\
\text { VIKOR }\end{array}$ & $\begin{array}{l}\text { Yabancı bankaların daha iyi performans } \\
\text { gösterdiği sonucuna ulaşılmıştır. }\end{array}$ \\
\hline $\begin{array}{l}\text { Akyüz vd., } \\
\text { (2011) }\end{array}$ & $\begin{array}{l}\text { BİST’te Seramik } \\
\text { sektöründeki bir anonim } \\
\text { şirketin performansının } \\
\text { analizi }\end{array}$ & $\begin{array}{l}1999- \\
2008\end{array}$ & TOPSİS & $\begin{array}{c}\text { İşletmenin en başarılı yılının } 2005 \text { olduğu, } \\
\text { başarının en düşük } 3 \text { yıllar sırasıyla; } 2003 \\
\text { (\%33), } 2000 \text { (\%51) ve } 2002 \text { (\%57) } \\
\text { şeklindedir. }\end{array}$ \\
\hline
\end{tabular}




\section{Materyal ve Yöntem}

Bu çalışmanın amacı 2007 yılından itibaren İstanbul'da şehir içi toplu taşıma alanında faaliyet göstermekte olan İstanbul Otobüs İşletmeleri Ticaret Anonim Şirketi'nin 2011-2018 y1lları arasındaki finansal performansını değerlendirmektir. Bu amaçla çok kriterli karar verme (ÇKKV) yöntemleri kullanılmıştır,

$\mathrm{Bu}$ çalışmada işletmelerin finansal performansını değerlendirmesine yönelik olarak yapılan literatür taraması sonucunda finansal performansını değerlendirmesin de yaygın olarak kullanılan kriterler belirlenmiştir. Belirlenen bu kriterler ("cari oran", "likidite oranı/asit testi oranı", " nakit oran”, " aktif devir hızı", " alacak devir hızı oranı", "öz kaynak devir hızı =net satışlar/ öz kaynak", " toplam borç oranı", " borç/öz kaynak oranı", “ kısa vadeli borç/toplam aktif oranı”, " kısa vadeli borç/toplam borç oranı”, “ öz kaynaklar /toplam varlıklar”, " net kar/net satışlar”, " aktifler karlılığ1 oranı”, ve "öz kaynak karlılığı oranı”) analizlerde kıyaslama değişkeni olarak kullanılmıştır. Kriterler finansal performansı olumlu ve olumsuz etkilemesine göre 2 sınıfa ayrılmıştır. Kriterlere ilişkin açılamalar Tablo 2'de verilmiştir

Tablo 2: Çalışmada Kullanılan Kriterler ve Kriter Kodları

\begin{tabular}{|l|l|l|l|}
\hline $\begin{array}{l}\text { Kriter } \\
\text { Kodu }\end{array}$ & Kriter & Kriter formülü & Etkisi \\
\hline K1 & Cari Oran & Dönen Varlıklar/KVB & Olumlu \\
\hline K2 & Likidite Oranı/Asit testi oranı & (Dönen Varlıklar-Stoklar)/KVB & Olumlu \\
\hline K3 & Nakit Oran & $\begin{array}{l}\text { (Hazır Değerler + Menkul Kıymetler) / Kısa Vadeli } \\
\text { Yabancı Kaynaklar }\end{array}$ & Olumlu \\
\hline K4 & Aktif Devir Hızı & Net Satışlar/Toplam Aktif & Olumlu \\
\hline K5 & Alacak Devir Hızı Oranı & Net Satışlar/Ticari Alacaklar & Olumlu \\
\hline K6 & Öz kaynak Devir Hızı & Öz kaynak Devir Hızı =Net Satışlar/ Öz kaynak & Olumlu \\
\hline K7 & Toplam Borç Oranı & Toplam Borç/Toplam Aktifler & Olumsuz \\
\hline K8 & Borç/Öz kaynak Oranı & Toplam Borç/Öz kaynak & Olumsuz \\
\hline K9 & K1sa Vadeli Borç/Toplam Aktif Oranı & Kısa Vadeli Borç/Toplam Aktif & Olumsuz \\
\hline K10 & K1sa Vadeli Borç/Toplam Borç Oranı & Kısa Vadeli Borç/Toplam Borç & Olumlu \\
\hline K11 & Öz kaynaklar/Toplam Varlıklar & Öz kaynaklar/Toplam Varlıklar & Olumlu \\
\hline K12 & Net Kar/Net Satışlar & Net Kar/Net Satışlar & Olumlu \\
\hline K13 & Aktifler Karlılığı Oranı & Net Kar/Toplam Aktifler & Olumlu \\
\hline K14 & Öz kaynak Karlılığ1 Oranı & Net Kar/Öz kaynak & Olumlu \\
\hline
\end{tabular}

Otobüs AȘ’nin finansal performansını değerlendirmesine kullanılan kriterlere ilişkin veriler kamuoyuna açık biçimde sunulan işletmenin kurumsal web sayfasında (http://www.otobus.istanbul) yer alan dokumlar kısmının mali tablolar bölümünden elde edilmiştir. Çalışmanın analiz kısmında işletmelerin finansal performansını değerlendirmesine kullanılan kriterlerin önem dereceleri (ağırlıkları) CRITIC yöntemiyle belirlenmiştir. Elde edilen bu kriter ağırlıkları kullanılarak TOPSIS yöntemiyle yapılan analizler sonucunda Otobüs AŞ’nin yıllara göre finansal performans bazlı sıralamaları yapılmıştır.

$\mathrm{Bu}$ çalışma, araştırmada kullanılan kriter kombinasyonları bakımından diğer çalışmalardan ayrılmaktadır. Bu çalışmamın önemli kısıtı analizlere dahil edilen yıllarla ilgilidir. Otobüs AŞ sadece 2011-2018 döneminin verilerine ulaşılabildiğinden çalışma sadece bu dönemdeki sekiz yılı kapsamaktadır.

\subsection{CRITIC Yöntemi}

CRITIC yöntemi herhangi bir kişisel değerlendirme olmaksızın doğrudan analizlerde kullanılacak veriler yardımıyla kriterlerin önem derecelerinin (ağırlıklarının) tespit edilebilmesi için geliştirmiştir (Şenol ve Ulutaş, 2018:93). ÇKKV yöntemleriyle yapılan analizlerde kullanılan 
kriterlerin önem derecelerinin (ağırlıkları) objektif olarak belirlenebilmesine olanak sağlamasından dolayı CRITIC yöntemi sıklıkla kullanılmaktadır (Kiracı ve Bakır, 2019).

CRITIC yöntemi aşağıdaki aşamalardan oluşmaktadır (Çakır ve Perçin, 2013:451; Işık, 2019:547-549; Şenol ve Ulutaş, 201:93-94; Kiracı ve Bakır, 20:160-161).

Adım 1 Karar Matrisinin Oluşturulması: CRITIC yönteminin ilk adımında diğer ÇKKV yöntemlerinde olduğu gibi karar problemine ilişkin kriter ve alternatiflerin yer aldığ 1 karar matrisi oluşturulur (Eşitlik 1).

$$
A_{i j}=\left[\begin{array}{cccc}
a_{11} & a_{12} & \ldots & a_{1 n} \\
a_{21} & a_{22} & \ldots & a_{2 n} \\
\cdot & & & \cdot \\
\cdot & & & \cdot \\
\cdot & & & \cdot \\
a_{m 1} & a_{m 2} & \ldots & a_{m n}
\end{array}\right]
$$

Eşitlik 1'de görüldüğü gibi karar matrisinde $\mathrm{n}$ adet kriter ve $\mathrm{m}$ adet alternatif yer almaktadır.

Adım 2 Normalize Edilmiş Karar Matrisinin Oluşturulması: Uygulamanın ikinci adımında kriter değerlerinin ortak birime dönüştürülmesi amacıyla (anomalileri yok etme) eşitlik (2) yardımıyla normalizasyon işlemi gerçekleştirilir.

$$
\begin{aligned}
& r_{i j}=\frac{x_{i j}-x_{i j} \min }{x_{i j}{ }^{\max }-x_{i j} \min } \\
& x_{i j}{ }^{\text {max }}=\mathrm{j} \text { kriterine ait en yüksek değer }, x_{i j}{ }^{\text {min }}=\mathrm{j} \text { kriterine ait en düşük değer }
\end{aligned}
$$

$r_{i j}$ her bir değerin normalize edilmiş halini ifade ederken normalizasyon işleminde kriterlerin fayda/maliyet durumu dikkate alınmamaktadır (Adalı ve Işık, 2017).

Adım 3 Kriterler Arası İkili Korelasyonların Hesaplanması: Bu adımda kriterler arasında ilişkinin gücünü tespit etmek amacıyla eşitlik (3) yardımıyla kriter çiftleri arasındaki korelasyon katsayıları hesaplanır.

$$
\rho_{j k}=\frac{\sum_{i=1}^{m}\left(r_{i j}-\bar{r}_{j}\right)\left(r_{i k}-\bar{r}_{k}\right)}{\sqrt{\sum_{i=1}^{m}\left(r_{i j}-\bar{r}_{j}\right)^{2} \sum_{i=1}^{m}\left(r_{i k}-\bar{r}_{k}\right)^{2}}}
$$

Eşitlik (3)'de görüldüğü gibi Pearson korelasyonu katsayısı kullanılırken, alternatif sayısının nispeten az olduğu durumlarda testin non-parametrik karşılığı olan Spearman sıra korelasyonu katsayıları kullanılmaktadır (Çakır ve Perçin, 2013).

Adım 4 Bilgi Miktarının $\left(c_{j}\right)$ Hesaplanması: Bu adımda her bir kriterin içerdiği toplam bilgi miktarı $\left(c_{j}\right)$ eşitlik (4) yardımıyla hesaplanır. Bu işlem gerçekleştirilirken normalize edilmiş karar matrisi sütun değerlerinin standart sapmasından $\left(\sigma_{j}\right)$ faydalanılır.

$$
c_{j}=\sigma_{j} \sum_{k=1}^{n}\left(1-\rho_{j k}\right)
$$

Adım 5 Kriter Ağırlıklarının Elde Edilmesi: CRITIC yönteminin son adımını oluşturan bu adımda j. kriterin ağırlık katsayısını ifade eden kriter ağırlıkları $\left(w_{j}\right)$ hesaplanır. Eşitlik (5) yardımıyla gerçekleştirilen ağırlıklandırma işleminde en yüksek değere sahip kriterin en yüksek önem düzeyine sahip (en önemli) kriter olduğu kabul edilir.

$$
w_{j}=\frac{c_{j}}{\sum_{k=1}^{n} c_{k}}
$$




\subsection{TOPSIS Yöntemi}

TOPSIS (Technique For Order Preference By Similarity To An Ideal Solution) yöntemi, 1981'de Hwang ve Yoon tarafından sunulan literatürde sıklıkla kullanılan önemli birçok kriterli karar verme tekniğidir. TOPSIS nitel bir değerlendirme yapılmasına gerek kalmaksızın, veri üzerinde direkt olarak analizlerin yapılmasına imkan sağlayabilmektedir (Ertuğrul ve Özçil, 2014:271). TOPSIS yöntem, negatif ideal çözümden en uzak olan ve pozitif ideal çözüme en yakın olan alternatifleri belirleyerek siralamayı yapmaktadır (Yavuz ve Deveci, 2014:466). TOPSIS yöntemi, rasyonellik ve kolay kavranabilirlik, hesaplamadaki basitlik ve kriterlerinin ağırlıklandırılmasına olanak sağlaması vb. avantajlar sebebiyle literatürde sıklıkla kullanılmaktadır. (Ertuğrul ve Özçil, 2014:271). TOPSIS yöntemi 8 aşamada uygulanmaktadır. Uygulama aşamaları aşağıda anlatılmıştır (Çakır ve Perçin, 2013:452; Perçin ve Sönmez, 2018: 571-572).

Aşama 1: Amaçların ve değerlendirme kriterlerinin tespit edilmesi: Üstünlüklerine göre kıyaslanacak seçenekler (alternatifler) ve bu seçeneklerin kıyaslanacağ kriterler tespit edilir.

Aşama 2: Karar matrisinin oluş̧turulması: Karar matrisinin satırlarında üstünlükleri göre kıyaslanacak seçenekler (alternatifler), sütunlarında ise seçeneklerin kıyaslanmasında kullanılacak kriterler bulunmaktadır. Karar matrisi aşağıdaki gibidir.

$$
A_{i j}=\left[\begin{array}{cccc}
a_{11} & a_{12} & \ldots & a_{1 n} \\
a_{21} & a_{22} & \ldots & a_{2 n} \\
\cdot & & & \cdot \\
\cdot & & & \cdot \\
\cdot & & & \cdot \\
a_{m 1} & a_{m 2} & \ldots & a_{m n}
\end{array}\right]
$$

Aşama 3: Karar matrisinin Eşitlik 1'deki gibi normalize edilmesi:

$$
r_{i j=\frac{a_{i j}}{\sqrt{\sum_{i=1}^{j} a_{i j}^{2}}}} \quad, \quad \mathrm{i}=1,2,3, \ldots . \mathrm{m} ; \quad \mathrm{j}=1,2,3, \ldots ., \mathrm{n}
$$

Aşama 4: Ağırlıklandırılmış normalize edilmiş karar matrisinin formülize edilmesi:

$$
v_{i j}=w_{i} * r_{i j}, \quad \mathrm{j}=1,2,3, \ldots, \mathrm{J}, \quad \mathrm{i}=1,2,3, \ldots, \mathrm{n}
$$

Aşama 5: Pozitif ideal çözüm (PIS) ve negatif ideal çözümün (NIS) belirlenmesi:

$$
\begin{aligned}
& A^{*}=\left\{v_{1}^{*}, v_{2}^{*}, \ldots, v_{n}^{*}\right\}=\{(\max v i j \mid i \in O),(\min v i j \mid i \in I)\} \text { maksimum değerler } \\
& A^{-}=\left\{v_{1}^{-}, v_{2}^{-}, \ldots, v_{n}^{-}\right\}=\{(\min v i j \mid i \in O),(\max v i j \mid i \in I)\} \text { minimum değerler }
\end{aligned}
$$

Aşama 6: Pozitif ideal çözüm (PIS) ve negatif ideal çözüm (NIS)'den her bir alternatifin uzaklığı hesaplanır:

$$
\begin{aligned}
& d_{i}^{*}=\sqrt{\sum_{j=1}^{n}\left(v_{i j}-v_{j}^{*}\right)^{2}}, \quad \mathrm{j}=1,2, \ldots \ldots, \mathrm{J} \\
& d_{i}^{*}=\sqrt{\sum_{j=1}^{n}\left(v_{i j}-v_{j}^{-}\right)^{2}}, \mathrm{j}=1,2, \ldots \ldots, \mathrm{J}
\end{aligned}
$$

Aşama 7: Her alternatifin yakınlık katsayısının hesaplanması:

$$
C C_{i}=\frac{d_{i}^{-}}{d_{i}^{*}+d_{i}^{-}} \quad, \mathrm{i}=1,2, \ldots, \mathrm{J} \quad 0 \leq \mathrm{CCi} \leq 1
$$

Aşama 8: CCi değerlerinin karşılaştırılması ve alternatiflerin sıralarının belirlenmesi. 


\section{Bulgular}

Otobüs AŞ 2011-2018 yılları arasındaki finansal performansının çok kriterli karar verme (ÇKKV) yöntemlerinden CRITIC ve TOPSIS yöntemleriyle değerlendirmesinde elde edilen bulgular bu bölümde sunulmuştur.

\subsection{CRITIC Yöntemi Bulgular}

Adım 1: Karar Matrisinin Oluşturulması: CRITIC yönteminin ilk adımında karar matrisi oluşturulmuştır. Tablo 3'te görüldüğü gibi, eşitlik (1) kullanılarak karar matrisi oluş̧urulmuştur. Karar matrisi 8 alternatif ve 14 kriterden oluşmaktadır. Kriter özellikleri değerlendirildiğinde Tablo 2'de görüldüğü gibi üçünün (K7, K8 ve K9) finassal performansı olumsuz etkileyen özellikte (minimum düzeyde olması istenilen) olduğu, buna karşın diğer kriterlerin ise fayda özellikli (maksimum düzeyde olması istenilen) olduğu görülmektedir.

Tablo 3: Karar matrisi

\begin{tabular}{|c|c|c|c|c|c|c|c|c|c|c|c|c|c|c|}
\hline & K1 & K2 & K3 & K4 & K5 & K6 & K7 & K8 & K9 & K10 & K11 & K12 & K13 & K14 \\
\hline 2011 & 2,499 & 2,499 & 2,168 & 0,180 & 3,479 & 2,787 & 0,935 & 14,504 & 0,364 & 0,389 & 0,065 & 0,123 & 0,022 & 0,343 \\
\hline 2012 & 6,426 & 6,426 & 5,071 & 0,606 & 3,790 & 5,328 & 0,886 & 7,794 & 0,151 & 0,170 & 0,114 & 0,123 & 0,075 & 0,657 \\
\hline 2013 & 13,720 & 13,720 & 12,003 & 0,689 & 7,677 & 4,919 & 0,860 & 6,135 & 0,072 & 0,083 & 0,140 & 0,097 & 0,067 & 0,479 \\
\hline 2014 & 9,613 & 9,600 & 1,682 & 0,980 & 1,840 & 7,763 & 0,874 & 6,924 & 0,094 & 0,108 & 0,126 & 0,019 & 0,018 & 0,144 \\
\hline 2015 & 50,704 & 50,377 & 7,746 & 1,208 & 2,114 & 8,090 & 0,851 & 5,695 & 0,018 & 0,021 & 0,149 & 0,028 & 0,033 & 0,223 \\
\hline 2016 & 8,125 & 8,125 & 0,344 & 1,339 & 2,270 & 8,823 & 0,848 & 5,591 & 0,112 & 0,131 & 0,152 & 0,041 & 0,055 & 0,363 \\
\hline 2017 & 5,188 & 5,121 & 0,243 & 1,415 & 2,714 & 37,117 & 15,092 & 22,102 & 3,208 & 0,213 & 0,683 & 0,003 & 0,004 & 0,095 \\
\hline 2018 & 2,945 & 2,945 & 0,100 & 1,769 & 7,291 & 9,845 & 0,820 & 4,564 & 0,226 & 0,275 & 0,180 & 0,006 & 0,011 & 0,063 \\
\hline Min & 2,499 & 2,499 & 0,100 & 0,180 & 1,840 & 2,787 & 0,820 & 4,564 & 0,018 & 0,021 & 0,065 & 0,003 & 0,004 & 0,063 \\
\hline Max & 50,704 & 50,377 & 12,003 & 1,769 & 7,677 & 37,117 & 15,092 & 22,102 & 3,208 & 0,389 & 0,683 & 0,123 & 0,075 & 0,657 \\
\hline
\end{tabular}

Adım 2: Normalize Edilmiş Karar Matrisinin Oluşturulması: Uygulamanın ikinci adımında kriter değerlerinin ortak birime dönüştürülmesi eşitlik (2) kullanılarak normalizasyon gerçekleştirilmiştir. $\mathrm{Bu}$ adımda normalizasyon işlemine ek olarak bilgi miktarının $\left(c_{j}\right)$ hesaplanmasında kullanılan standart sapma $\left(\sigma_{j}\right)$ değerleri de hesaplanmıştır. Tablo 4 'te görüldüğü gibi en alt satırda yer almaktadır.

Tablo 4: Normalize Edilmiş Karar Matrisi

\begin{tabular}{|c|c|c|c|c|c|c|c|c|c|c|c|c|c|c|}
\hline & K1 & K2 & K3 & K4 & K5 & K6 & K7 & K8 & K9 & K10 & K11 & K12 & K13 & K14 \\
\hline 2011 & 0,000 & 0,000 & 0,174 & 0,000 & 0,281 & 0,000 & 0,992 & 0,433 & 0,892 & 1,000 & 0,000 & 0,998 & 0,260 & 0,472 \\
\hline 2012 & 0,081 & 0,082 & 0,418 & 0,268 & 0,334 & 0,074 & 0,995 & 0,816 & 0,958 & 0,406 & 0,080 & 1,000 & 1,000 & 1,000 \\
\hline 2013 & 0,233 & 0,234 & 1,000 & 0,321 & 1,000 & 0,062 & 0,997 & 0,910 & 0,983 & 0,169 & 0,122 & 0,785 & 0,893 & 0,700 \\
\hline 2014 & 0,148 & 0,148 & 0,133 & 0,503 & 0,000 & 0,145 & 0,996 & 0,865 & 0,976 & 0,237 & 0,100 & 0,133 & 0,205 & 0,137 \\
\hline 2015 & 1,000 & 1,000 & 0,642 & 0,647 & 0,047 & 0,154 & 0,998 & 0,936 & 1,000 & 0,000 & 0,137 & 0,207 & 0,418 & 0,270 \\
\hline 2016 & 0,117 & 0,118 & 0,021 & 0,729 & 0,074 & 0,176 & 0,998 & 0,941 & 0,971 & 0,300 & 0,141 & 0,320 & 0,724 & 0,506 \\
\hline 2017 & 0,056 & 0,055 & 0,012 & 0,777 & 0,150 & 1,000 & 0,000 & 0,000 & 0,000 & 0,521 & 1,000 & 0,000 & 0,000 & 0,055 \\
\hline 2018 & 0,009 & 0,009 & 0,000 & 1,000 & 0,934 & 0,206 & 1,000 & 1,000 & 0,935 & 0,690 & 0,186 & 0,031 & 0,107 & 0,000 \\
\hline $\boldsymbol{\sigma j}$ & 0,330 & 0,330 & 0,362 & 0,323 & 0,396 & 0,320 & 0,352 & 0,346 & 0,341 & 0,318 & 0,320 & 0,426 & 0,376 & 0,345 \\
\hline
\end{tabular}

Adım 3: Kriterler Arası İkili Korelasyonların Hesaplanması: Bu adımda kriterler arasında ilişkinin gücünün belirlenebilmesi için eşitlik (3) kullanılarak kriterler arasındaki korelasyon katsayıları hesaplanmıştır. Elde edilen değerler Tablo 5'te yer almaktadır. 
Tablo 5: Kriterler Aras1 Korelasyon Katsayıları

\begin{tabular}{|c|c|c|c|c|c|c|c|c|c|c|c|c|c|c|}
\hline & K1 & K2 & K3 & K4 & K5 & K6 & K7 & K8 & K9 & K10 & K11 & K12 & K13 & K14 \\
\hline K1 & 1,000 & 1,000 & 0,525 & 0,112 & $-0,270$ & $-0,134$ & 0,185 & 0,311 & 0,246 & $-0,688$ & $-0,138$ & $-0,188$ & 0,094 & $-0,061$ \\
\hline K2 & 1,000 & 1,000 & 0,527 & 0,111 & $-0,269$ & $-0,135$ & 0,187 & 0,312 & 0,247 & $-0,689$ & $-0,140$ & $-0,187$ & 0,096 & $-0,059$ \\
\hline K3 & 0,525 & 0,527 & 1,000 & $-0,408$ & 0,375 & $-0,393$ & 0,321 & 0,333 & 0,367 & $-0,547$ & $-0,319$ & 0,456 & 0,613 & 0,528 \\
\hline K4 & 0,112 & 0,111 & $-0,408$ & 1,000 & 0,054 & 0,498 & $-0,303$ & 0,136 & $-0,273$ & $-0,233$ & 0,455 & $-0,893$ & $-0,413$ & $-0,666$ \\
\hline K5 & $-0,270$ & $-0,269$ & 0,375 & 0,054 & 1,000 & $-0,216$ & 0,209 & 0,283 & 0,189 & 0,181 & $-0,150$ & 0,201 & 0,194 & 0,124 \\
\hline K6 & $-0,134$ & $-0,135$ & $-0,393$ & 0,498 & $-0,216$ & 1,000 & $-0,976$ & $-0,752$ & $-0,963$ & 0,050 & 0,995 & $-0,580$ & $-0,530$ & $-0,506$ \\
\hline K7 & 0,185 & 0,187 & 0,321 & $-0,303$ & 0,209 & $-0,976$ & 1,000 & 0,864 & 0,996 & $-0,137$ & $-0,984$ & 0,408 & 0,484 & 0,393 \\
\hline K8 & 0,311 & 0,312 & 0,333 & 0,136 & 0,283 & $-0,752$ & 0,864 & 1,000 & 0,894 & $-0,461$ & $-0,766$ & 0,040 & 0,480 & 0,226 \\
\hline K9 & 0,246 & 0,247 & 0,367 & $-0,273$ & 0,189 & $-0,963$ & 0,996 & 0,894 & 1,000 & $-0,230$ & $-0,971$ & 0,375 & 0,514 & 0,397 \\
\hline K10 & $-0,688$ & $-0,689$ & $-0,547$ & $-0,233$ & 0,181 & 0,050 & $-0,137$ & $-0,461$ & $-0,230$ & 1,000 & 0,049 & 0,257 & $-0,408$ & $-0,124$ \\
\hline K11 & $-0,138$ & $-0,140$ & $-0,319$ & 0,455 & $-0,150$ & 0,995 & $-0,984$ & $-0,766$ & $-0,971$ & 0,049 & 1,000 & $-0,524$ & $-0,484$ & $-0,455$ \\
\hline K12 & $-0,188$ & $-0,187$ & 0,456 & $-0,893$ & 0,201 & $-0,580$ & 0,408 & 0,040 & 0,375 & 0,257 & $-0,524$ & 1,000 & 0,663 & 0,870 \\
\hline K13 & 0,094 & 0,096 & 0,613 & $-0,413$ & 0,194 & $-0,530$ & 0,484 & 0,480 & 0,514 & $-0,408$ & $-0,484$ & 0,663 & 1,000 & 0,925 \\
\hline K14 & $-0,061$ & $-0,059$ & 0,528 & $-0,666$ & 0,124 & $-0,506$ & 0,393 & 0,226 & 0,397 & $-0,124$ & $-0,455$ & 0,870 & 0,925 & 1,000 \\
\hline
\end{tabular}

Adım 4: Bilgi Miktarının $\left(c_{j}\right)$ Hesaplanması: Bu adımda her bir kriterin içerdiği toplam bilgi miktarı $\left(C_{j}\right)$ eşitlik (4) yardımıyla hesaplanmıştır. Elde edilen değerler Tablo 6' da yer almaktadır.

Adım 5: Kriter Ağırlıklarının Elde Edilmesi: Bu adımda kriterin ağırlık katsayısını ifade eden kriter ağırlıkları $\left(w_{j}\right)$ Eşitlik (5) kullanılarak hesaplanmıştır. En yüksek değere sahip kriterin en yüksek önem düzeyine sahip (en önemli) kriter olduğu kabul edilmektedir. Elde edilen değerler Tablo 6'da yer almaktadır.

Tablo 6: Hesaplanan Değerleri $\left(c_{j}\right)$ ve Değerlendirme Kriterlerinin Ağırlıkları $\left(w_{j}\right)$

\begin{tabular}{|c|c|c|c|c|c|c|c|c|c|c|c|c|c|c|}
\hline & $\mathrm{K} 1$ & $\mathrm{~K} 2$ & $\mathrm{~K} 3$ & $\mathrm{~K} 4$ & $\mathrm{~K} 5$ & $\mathrm{~K} 6$ & $\mathrm{~K} 7$ & $\mathrm{~K} 8$ & $\mathrm{~K} 9$ & $\mathrm{~K} 10$ & $\mathrm{~K} 11$ & $\mathrm{~K} 12$ & $\mathrm{~K} 13$ & $\mathrm{~K} 14$ \\
\hline K1 & 0,000 & 0,000 & 0,475 & 0,888 & 1,270 & 1,134 & 0,815 & 0,689 & 0,754 & 1,688 & 1,138 & 1,188 & 0,906 & 1,061 \\
\hline K2 & 0,000 & 0,000 & 0,473 & 0,889 & 1,269 & 1,135 & 0,813 & 0,688 & 0,753 & 1,689 & 1,140 & 1,187 & 0,904 & 1,059 \\
\hline K3 & 0,475 & 0,473 & 0,000 & 1,408 & 0,625 & 1,393 & 0,679 & 0,667 & 0,633 & 1,547 & 1,319 & 0,544 & 0,387 & 0,472 \\
\hline K4 & 0,888 & 0,889 & 1,408 & 0,000 & 0,946 & 0,502 & 1,303 & 0,864 & 1,273 & 1,233 & 0,545 & 1,893 & 1,413 & 1,666 \\
\hline K5 & 1,270 & 1,269 & 0,625 & 0,946 & 0,000 & 1,216 & 0,791 & 0,717 & 0,811 & 0,819 & 1,150 & 0,799 & 0,806 & 0,876 \\
\hline K6 & 1,134 & 1,135 & 1,393 & 0,502 & 1,216 & 0,000 & 1,976 & 1,752 & 1,963 & 0,950 & 0,005 & 1,580 & 1,530 & 1,506 \\
\hline K7 & 0,815 & 0,813 & 0,679 & 1,303 & 0,791 & 1,976 & 0,000 & 0,136 & 0,004 & 1,137 & 1,984 & 0,592 & 0,516 & 0,607 \\
\hline K8 & 0,689 & 0,688 & 0,667 & 0,864 & 0,717 & 1,752 & 0,136 & 0,000 & 0,106 & 1,461 & 1,766 & 0,960 & 0,520 & 0,774 \\
\hline K9 & 0,754 & 0,753 & 0,633 & 1,273 & 0,811 & 1,963 & 0,004 & 0,106 & 0,000 & 1,230 & 1,971 & 0,625 & 0,486 & 0,603 \\
\hline K10 & 1,688 & 1,689 & 1,547 & 1,233 & 0,819 & 0,950 & 1,137 & 1,461 & 1,230 & 0,000 & 0,951 & 0,743 & 1,408 & 1,124 \\
\hline K11 & 1,138 & 1,140 & 1,319 & 0,545 & 1,150 & 0,005 & 1,984 & 1,766 & 1,971 & 0,951 & 0,000 & 1,524 & 1,484 & 1,455 \\
\hline K12 & 1,188 & 1,187 & 0,544 & 1,893 & 0,799 & 1,580 & 0,592 & 0,960 & 0,625 & 0,743 & 1,524 & 0,000 & 0,337 & 0,130 \\
\hline K13 & 0,906 & 0,904 & 0,387 & 1,413 & 0,806 & 1,530 & 0,516 & 0,520 & 0,486 & 1,408 & 1,484 & 0,337 & 0,000 & 0,075 \\
\hline K14 & 1,061 & 1,059 & 0,472 & 1,666 & 0,876 & 1,506 & 0,607 & 0,774 & 0,603 & 1,124 & 1,455 & 0,130 & 0,075 & 0,000 \\
\hline & & & & & & & & & & & & & & \\
\hline$c_{j}$ & 3,961 & 3,958 & 3,842 & 4,785 & 4,793 & 5,318 & 4,001 & 3,842 & 3,821 & 5,079 & 5,251 & 5,152 & 4,054 & 3,931 \\
\hline$w_{j}$ & 0,064 & 0,064 & 0,062 & 0,077 & 0,078 & 0,086 & 0,065 & 0,062 & 0,062 & 0,082 & 0,085 & 0,083 & 0,066 & 0,064 \\
\hline
\end{tabular}

\subsection{TOPSIS Yöntemi Bulgular}

Otobüs AŞ’nin finansal performansının değerlendirmesinde kullanılan kriterlere ilişkin önem dereceleri (ağırlıkları) CRITIC yöntemleriyle bir önceki aşamada belirlenmiştir. Bu aşamada 
CRITIC yöntemiyle belirlenen kriter ağırlıkları da kullanılarak TOPSIS yöntemiyle yapılan analizler sonucunda Otobüs AŞ’nin yıllara göre finansal performans bazlı sıralamaları yapılmıştır. TOPSIS yöntemi uygulama adımlarında aşağıdaki bulgular elde edilmiştir.

Aşama 1: Amaçların ve Değerlendirme Kriterlerinin Tespit Edilmesi: Üstünlüklerine göre kıyaslanacak alternatifler/seçenekler (2011, 2012, 2013, 2014 2015, 2016, 2017 ve 2018) ve bu seçeneklerin kıyaslanacağı kriterler \{Cari Oran (K1), Likidite Oran1/Asit testi oranı (K2), Nakit Oran (K3), Aktif Devir Hızı (K4), Alacak Devir Hızı Oranı (K5), Öz kaynak Devir Hızı (K6), Toplam Borç Oranı (K7), Borç/Öz kaynak Oranı (K8), Kısa Vadeli Borç/Toplam Aktif Oranı (K9), Kısa Vadeli Borç/Toplam Borç Oranı (K10), Öz kaynaklar /Toplam Varlıklar (K11), Net Kar/Net Satışlar (K12), Aktifler Karlılığı Oranı (K13) ve Öz kaynak Karlılığı Oranı (K14)\} tespit edilmiştir. Kriter özellikleri değerlendirildiğinde Tablo 2'de görüldüğü gibi üçünün (K7, K8 ve K9) finassal performansı olumsuz etkileyen özellikte (minimum düzeyde olması istenilen) olduğu, buna karşın diğer kriterlerin ise fayda özellikli (maksimum düzeyde olması istenilen) olduğu görülmektedir.

Aşama 2: TOPSIS Yöntemi Karar Matrisinin Oluşturulması: TOPSIS yönteminde de tüm çok kriterli karar verme yöntemlerinde olduğu gibi ilk aşamada (6) numaralı eşitlik yardımıyla karar matrisi oluşturulmuştur. Karar matrisi 8 alternatiften ve 14 kriterden oluşan 8x14 tipinde bir matristir. Oluşturulan A karar matrisi aşağıdaki Tablo 7'de görüldüğü gibidir. Ayrıca Tablo 7'de en alt satırda CRITIC yöntemiyle elde edilen kriterlerinin ağırlık değerleri de verilmiştir.

Tablo 7: TOPSIS Yöntemine İlişkin Karar Matrisi ve Kriterlerinin Ağırlık Değerleri

\begin{tabular}{|c|c|c|c|c|c|c|c|c|c|c|c|c|c|c|}
\hline & Maks. & Maks. & Maks. & Maks. & Maks. & Maks. & Min. & Min. & Min. & Maks. & Maks. & Maks. & Maks. & Maks. \\
\hline & K1 & K2 & K3 & K4 & K5 & K6 & K7 & K8 & K9 & K10 & K11 & K12 & K13 & K14 \\
\hline 2011 & 2,50 & 2,50 & 2,17 & 0,18 & 3,48 & 2,79 & 0,94 & 14,50 & 0,36 & 0,39 & 0,06 & 0,12 & 0,02 & 0,34 \\
\hline 2012 & 6,43 & 6,43 & 5,07 & 0,61 & 3,79 & 5,33 & 0,89 & 7,79 & 0,15 & 0,17 & 0,11 & 0,12 & 0,07 & 0,66 \\
\hline 2013 & 13,72 & 13,72 & 12,00 & 0,69 & 7,68 & 4,92 & 0,86 & 6,14 & 0,07 & 0,08 & 0,14 & 0,10 & 0,07 & 0,48 \\
\hline 2014 & 9,61 & 9,60 & 1,68 & 0,98 & 1,84 & 7,76 & 0,87 & 6,92 & 0,09 & 0,11 & 0,13 & 0,02 & 0,02 & 0,14 \\
\hline 2015 & 50,70 & 50,38 & 7,75 & 1,21 & 2,11 & 8,09 & 0,85 & 5,70 & 0,02 & 0,02 & 0,15 & 0,03 & 0,03 & 0,22 \\
\hline 2016 & 8,13 & 8,13 & 0,34 & 1,34 & 2,27 & 8,82 & 0,85 & 5,59 & 0,11 & 0,13 & 0,15 & 0,04 & 0,06 & 0,36 \\
\hline 2017 & 5,19 & 5,12 & 0,24 & 1,42 & 2,71 & 37,12 & 15,09 & 22,10 & 3,21 & 0,21 & 0,68 & 0,00 & 0,00 & 0,10 \\
\hline 2018 & 2,94 & 2,94 & 0,10 & 1,77 & 7,29 & 9,84 & 0,82 & 4,56 & 0,23 & 0,27 & 0,18 & 0,01 & 0,01 & 0,06 \\
\hline & & & & & & & & & & & & & & \\
\hline w & $\mathbf{0 , 0 6 4}$ & $\mathbf{0 , 0 6 4}$ & $\mathbf{0 , 0 6 2}$ & $\mathbf{0 , 0 7 7}$ & $\mathbf{0 , 0 7 8}$ & $\mathbf{0 , 0 8 6}$ & $\mathbf{0 , 0 6 5}$ & $\mathbf{0 , 0 6 2}$ & $\mathbf{0 , 0 6 2}$ & $\mathbf{0 , 0 8 2}$ & $\mathbf{0 , 0 8 5}$ & $\mathbf{0 , 0 8 3}$ & $\mathbf{0 , 0 6 6}$ & $\mathbf{0 , 0 6 4}$ \\
\hline
\end{tabular}

Aşama 3: Normalize (standart) Karar Matrisinin (R) Oluşturulmasi: Karar matrisinden (7) numaralı eşitlik yardımıyla hesaplanan standart karar matrisi aşağıdaki Tablo $8^{`}$ de gösterilmiştir.

Tablo 8:TOPSIS Yöntemine Göre Normalize Edilmiș Karar Matrisi

\begin{tabular}{|c|c|c|c|c|c|c|c|c|c|c|c|c|c|c|}
\hline & Maks. & Maks. & Maks. & Maks. & Maks. & Maks. & Min. & Min. & Min. & Maks. & Maks. & Maks. & Maks. & Maks. \\
\hline & K1 & K2 & K3 & K4 & K5 & K6 & K7 & K8 & K9 & K10 & K11 & K12 & K13 & K14 \\
\hline 2011 & 0,046 & 0,046 & 0,141 & 0,056 & 0,276 & 0,067 & 0,061 & 0,476 & 0,112 & 0,669 & 0,084 & 0,596 & 0,180 & 0,344 \\
\hline 2012 & 0,117 & 0,118 & 0,329 & 0,190 & 0,301 & 0,128 & 0,058 & 0,256 & 0,047 & 0,293 & 0,147 & 0,597 & 0,606 & 0,659 \\
\hline 2013 & 0,250 & 0,252 & 0,779 & 0,216 & 0,609 & 0,118 & 0,056 & 0,201 & 0,022 & 0,143 & 0,181 & 0,471 & 0,544 & 0,480 \\
\hline 2014 & 0,175 & 0,176 & 0,109 & 0,306 & 0,146 & 0,186 & 0,057 & 0,227 & 0,029 & 0,186 & 0,163 & 0,090 & 0,148 & 0,145 \\
\hline 2015 & 0,926 & 0,925 & 0,503 & 0,378 & 0,168 & 0,194 & 0,056 & 0,187 & 0,006 & 0,036 & 0,193 & 0,134 & 0,270 & 0,224 \\
\hline 2016 & 0,148 & 0,149 & 0,022 & 0,419 & 0,180 & 0,212 & 0,056 & 0,183 & 0,034 & 0,226 & 0,196 & 0,199 & 0,447 & 0,364 \\
\hline 2017 & 0,095 & 0,094 & 0,016 & 0,443 & 0,215 & 0,890 & 0,989 & 0,725 & 0,989 & 0,366 & 0,884 & 0,012 & 0,030 & 0,096 \\
\hline 2018 & 0,054 & 0,054 & 0,006 & 0,553 & 0,578 & 0,236 & 0,054 & 0,150 & 0,070 & 0,473 & 0,233 & 0,031 & 0,091 & 0,063 \\
\hline
\end{tabular}


Aşama 4: Ağırlıklı Standart Karar Matrisinin Oluşturulması: Ağırlıklı Standart Karar matrisleri CRITIC yöntemiyle hesaplanmış kriter ağırlıkları kullanılarak (8) numaralı eşitlik yardımıyla hesaplanmıştır. Ağırlıklı Standart Karar Matrisi aşağıdaki Tablo 9`da sunulmuştur.

Aşama 5: İdeal (A*) ve Negatif İdeal (A-) Çözümlerin Oluşturulması: Pozitif ve negatif ideal çözüm kümeleri (9) ve (10) numaralı eşitlikler kullanarak hesaplanmış olan aşağıda Tablo 9'da en alt satırda verilmiştir. K7, K8 ve K9 dışındaki kriteler finansal performansı olumlu etkilediğinden bu kriterlerinin negatif ideal çözüm kümesi bulunurken minimizasyon yönlü ve pozitif ideal çözüm kümesi maksimizasyon yönlü olarak değerlendirilirken; K7, K8 ve K9 kriteleri finansal performans1 olumsuz etkilemesinden dolayı kriterlerinin negatif ideal çözüm kümesi bulunurken maksimizasyon yönlü ve pozitif ideal çözüm kümesi minimizasyon yönlü olarak değerlendirilmiştir.

Tablo 9: Ağırlıklı Standart Karar Matrisi ile İdeal (A*) ve Negatif İdeal (A-) Çözümler

\begin{tabular}{|c|c|c|c|c|c|c|c|c|c|c|c|c|c|c|}
\hline & Maks. & Maks. & Maks. & Maks. & Maks. & Maks. & Min. & Min. & Min. & Maks. & Maks. & Maks. & Maks. & Maks. \\
\hline & K1 & K2 & K3 & K4 & K5 & K6 & K7 & K8 & K9 & K10 & K11 & K12 & K13 & K14 \\
\hline 2011 & 0,003 & 0,003 & 0,009 & 0,004 & 0,021 & 0,006 & 0,004 & 0,030 & 0,007 & 0,055 & 0,007 & 0,050 & 0,012 & 0,022 \\
\hline 2012 & 0,008 & 0,008 & 0,020 & 0,015 & 0,023 & 0,011 & 0,004 & 0,016 & 0,003 & 0,024 & 0,013 & 0,050 & 0,040 & 0,042 \\
\hline 2013 & 0,016 & 0,016 & 0,048 & 0,017 & 0,047 & 0,010 & 0,004 & 0,013 & 0,001 & 0,012 & 0,015 & 0,039 & 0,036 & 0,031 \\
\hline 2014 & 0,011 & 0,011 & 0,007 & 0,024 & 0,011 & 0,016 & 0,004 & 0,014 & 0,002 & 0,015 & 0,014 & 0,007 & 0,010 & 0,009 \\
\hline 2015 & 0,059 & 0,059 & 0,031 & 0,029 & 0,013 & 0,017 & 0,004 & 0,012 & 0,000 & 0,003 & 0,016 & 0,011 & 0,018 & 0,014 \\
\hline 2016 & 0,010 & 0,010 & 0,001 & 0,032 & 0,014 & 0,018 & 0,004 & 0,011 & 0,002 & 0,019 & 0,017 & 0,017 & 0,029 & 0,023 \\
\hline 2017 & 0,006 & 0,006 & 0,001 & 0,034 & 0,017 & 0,077 & 0,064 & 0,045 & 0,061 & 0,030 & 0,075 & 0,001 & 0,002 & 0,006 \\
\hline 2018 & 0,003 & 0,003 & 0,000 & 0,043 & 0,045 & 0,020 & 0,003 & 0,009 & 0,004 & 0,039 & 0,020 & 0,003 & 0,006 & 0,004 \\
\hline & & & & & & & & & & & & & & \\
\hline A+ = & 0,059 & 0,059 & 0,048 & 0,043 & 0,047 & 0,077 & 0,003 & 0,009 & 0,000 & 0,055 & 0,075 & 0,050 & 0,040 & 0,042 \\
\hline A- = & 0,003 & 0,003 & 0,000 & 0,004 & 0,011 & 0,006 & 0,064 & 0,045 & 0,061 & 0,003 & 0,007 & 0,001 & 0,002 & 0,004 \\
\hline
\end{tabular}

Aşama 6: Ayırım Ölçülerinin Hesaplanması: Ayırım ölçüleri (11) ve (12) numaralı eşitlikler ile hesaplanmış ve Tablo 10'da gösterilmiştir.

Aşama 7: İdeal Çözüme Göreli Yakınlığın Hesaplanması: Yakınlık katsayıları (13) numaralı eşitlik kullanılarak hesaplanmış ve Tablo 10'da gösterilmiştir. Otobüs AŞ'nin 2011-2018 yılları arasındaki finansal performansını değerlendirmesinde CRITIC yöntemiyle elde edilen kritrer ağırlıkları baz alınarak TOPSIS yöntemiyle belirlenen sıralama 2015, 2013, 2012, 2018, 2016, 2011, 2017 ve 2014 biçimindedir.

Tablo 10: Pozitif ve Negatif İdeal Ayrım Ölçüleri ve İdeal Çözüme Göre Yakınlık Katsayıları

\begin{tabular}{|c|c|c|c|c|}
\hline \multicolumn{5}{|c|}{ CRITIC Ağırlıkı TOPSIS $(\mathbf{C}+\mathbf{T})$} \\
\hline Yıl & Si- & Si+ & Pi & Sıra \\
\hline 2011 & 0,112 & 0,146 & 0,433 & 6 \\
\hline 2012 & 0,120 & 0,129 & 0,480 & 3 \\
\hline 2013 & 0,126 & 0,121 & 0,511 & 2 \\
\hline 2014 & 0,095 & 0,144 & 0,398 & 8 \\
\hline 2015 & 0,131 & 0,119 & 0,523 & 1 \\
\hline 2016 & 0,105 & 0,135 & 0,438 & 5 \\
\hline 2017 & 0,106 & 0,153 & 0,411 & 7 \\
\hline 2018 & 0,112 & 0,141 & 0,442 & 4 \\
\hline
\end{tabular}




\section{Sonuç}

Bu çalışmada 2007 yılından itibaren İstanbul'da şehir içi toplu taşıma alanında faaliyet göstermekte olan İstanbul Otobüs İşletmeleri Ticaret Anonim Şirketi'nin 2011-2018 yılları arasındaki finansal performansı değerlendirilmiştir. Analizlerde kullanılan kriterlerin önem derecelerinin ağırlıkları, öznellikten uzak olarak belirlenebilmesine olanak sağlayan CRITIC yöntemiyle belirlenmiştir. CRITIC yöntemiyle belirlenen kriter ağırlıkları sıralamasına göre belirlenen kriterlerin en önemliden en önemsize doğru sıralaması, öz kaynak devir hızı, öz kaynaklar /toplam varlıklar, net kar/net satışlar, kısa vadeli borç/toplam borç oranı, alacak devir hızı oranı, aktif devir hızı, aktifler karlılı̆̆ı oranı, toplam borç oranı, likidite oranı/asit testi oranı, cari oran, öz kaynak karlılı̆̆1 oranı, nakit oran, borç/öz kaynak oranı ve kısa vadeli borç/toplam aktif oranı şeklindedir. Belirlenen kriter ağırlıkları kullanılarak TOPSIS yöntemiyle kullanılarak Otobüs AŞ'nin yıllara göre finansal performansları analiz edilmiştir. CRITIC ağırlıklı TOPSIS yöntemi kullanılarak yapılan analizler sonucunda; Otobüs AŞ’nin 2015 yılında en yüksek performansa sahip olduğu, 2014 yılında ise en kötü performansı gösterdiği tespit edilmiştir.

Elde edilen sonuçlar çerçevesinde yöneticiler; finansal performansın 2015 yılında yüksek çıkmasını sağlayan unsurları veya diğer yıllara göre farklılıkların neler olduğunu analiz ederek ve bu çerçevede işletmenin gelecek yıllarda performansını yükseltebilecek stratejiler oluşturulabilirler. Ters bakış açısıyla da 2014 yılında performansın neden düşük çıktığına yönelik benzer değerlendirmeler yapılarak bu doğrultuda gerekli tedbirler alınabilir ve performansı olumsuz etkileyen faktörlerin düzeltilmesine için çalışmalar yapabilirler.

$\mathrm{Bu}$ çalışmada kullanılan kriterlerin önem dereceleri objektif CRITIC yöntemleriyle belirlenmiştir. Gelecekte yapılacak çalışmalarda öznel değerlendirmeye imkan sağlayan yöntemler kullanılarak yapılırsa farklı sonuçlar elde edilebilir. Sıralama yapılırken TOPSIS yöntemleri kullanılmıştır. Gelecekte yapılacak çalışmalarda farklı çok kriterli karar verme (ÇKKV) yöntemleri kullanılırsa farklı sonuçlar elde edilebilir.

\section{Kaynakça}

Acar, M. (2003). “Tarımsal İşletmelerde Finansal Performans Analizi”, Erciyes Üniversitesi İktisadi ve İdari Bilimler Fakültesi Dergisi, Sayı.20, 21-37.

Adal1, E.ve Işık, A T. (2017). "Critic and Maut Methods for the Contract Manufacturer Selection Problem”.European Journal of Multidisciplinary Studies, 2(5), s.93-101

Akbulut, O. (2019). “CRITIC ve EDAS Yöntemleri İle İş Bankası'nın 2009-2018 Yı1ları Arasındaki Performansının Analizi”. Ekonomi Politika ve Finans Araştırmaları Dergisi, 4 (2), 249-263.

Akbulut, R. ve Rençber, Ö.F. (2015). BİST'te İmalat Sektöründeki İşletmelerin Finansal Performansları Üzerine Bir Araştırma. Muhasebe ve Finansman Dergisi, 65, 118-136.

Akgün, M. ve Temür, S. A. (2016), "BIST Ulaştırma Endeksine Kayıtlı Şirketlerin Finansal Performanslarının TOPSIS Yöntemi İle Değerlendirilmesi”, Uluslararası Yönetim İktisat ve İsletme Dergisi, ICAFR 16 Özel Sayıs1, 173-186.

Akyüz, İ., Aydemir, B., Bayram, B. H. ve Akyüz, K. C. 2019). Orman Ürünleri İşletmelerinin Finansal Performanslarının Entropi Temelli TOPSIS Yöntemi ile Karşılaştırılması: Artvin Örneği. Bartın Orman Fakültesi Dergisi. 21. 136-146.

Akyüz, Y., Bozdoğan, T. ve Hantekin, E. (2011). TOPSIS Yöntemiyle Finansal Performansın Değerlendirilmesi ve Bir Uygulama. Afyon Kocatepe Üniversitesi I.I.I.B.F. Dergisi, 13(1): 7392. 
Apan, M. \& Öztel, A. (2018). Ölçek Bazlı Finansal Performansın PROMETHEE Yöntemiyle Belirlenmesi: Farklı Ağırlıklandırma Yöntemlerine Dayalı Karşılaştırmalı Bir Analiz. İşletme Bilimi Dergisi, 6 (1) , 207-244.

Apan, M. \& Öztel, A. (2020). Girişim Sermayesi Yatııı Ortaklıklarının CRİTİC-PROMETHEE Bütünleşik Karar Verme Yöntemi ile Finansal Performans Değerlendirmesi: Borsa İstanbul'da Bir Uygulama. Dumlupınar Üniversitesi Sosyal Bilimler Dergisi, (63), 54-73.

Apan, M. \& Öztel, A. Ceyhan İ. F. (2019). Entropi Yöntemine Dayalı CAMELS Performans Değerlendirme Modeli: Türk Mevduat Bankalarının 2002-2016 Verisinin Ampirik Analizi, Akademik Araştırmalar ve Çalışmalar Dergisi, 11(20): 2296316.

Ayçin, E. (2019). BIST Menkul Kıymet Yatırım Ortaklıkları Endeksinde (XYORT) Yer Alan İşletmelerin Finansal Performanslarının Entropi ve Gri İlişkisel Analiz Bütünleşik Yaklaşımı İle Değerlendirilmesi. Dokuz Eylul Universitesi Iktisadi ve Idari Bilimler Dergisi. 33. 595622. 10.24988/deuiibf.2018332799.

Aydın, Y. (2019). "Türkiye'de HayattEmeklilik Sigorta Sektörünün Finansal Performans Analizi”. Finans Ekonomi ve Sosyal Araştırmalar Dergisi, 4(1), 107-118.

Bağcı, H. ve Rençber, Ö. F. (2014). "Kamu Bankaları ve Halka Açık Özel Bankaların PROMETHEE Yöntemi İle Kârlılıklarının Analizi”. Aksaray Üniversitesi İktisadi ve İdari Bilimler Fakültesi Dergisi. 6(1) . 39-47.

Bayyurt, N. (2011). İşletmelerde Performans Değerlendirmenin Önemi ve Performans Göstergeleri Arasındaki İlişkiler. Journal of Social Policy Conferences, 0 (53), 577-592.

Bulgurcu, B. K. (2012). Application of TOPSIS Technique For Financial Performance Evaluation Of Technology Firms In Istanbul Stock Exchange Market. Social and Behavioral Sciences, 62, 1033-1040.

Çakır, S. ve Perçin, S.(2013). "AB Ülkeleri’nde Bütünleşik Entropi Ağırlık-TOPSIS Yöntemiyle AR-GE Performansının Ölçülmesi”. Uludağ Üniversitesi İktisadi ve İdari Bilimler Fakültesi Dergisi, Cilt: XXXII, Say1:1, 77-95.

Deveci, M. ve Yavuz, S. (2014). "Bulanık TOPSIS ve Bulanık VIKOR Yöntemleriyle Alışveriş Merkezi Kuruluş Yeri Seçimi ve Bir Uygulama". Ege Akademik Bakis (Ege Academic Review). 14. 463-463.

Dinçer, H. ve Görener, A. (2011), "Performans Değerlendirmesinde Ahp - Vikor ve Ahp - TOPSIS Yaklaşımları: Hizmet Sektöründe Bir Uygulama", Sigma: Mühendislik ve Fen Bilimleri Dergisi, 29: 244-260.

Ege, İ. ve Yaman, S. (2018).TOPSIS ve MOORA Yöntemleri İle Ölçülen Finansal Performansın Pay Getirilerine Etkisi: Bist Çimento Beton İşletmeleri Üzerine Bir Panel Veri Uygulaması, INJOSOS Al-Farabı International Journal On Social Sciences, 2(1), 75-96.

Ege, İ., Topaloğlu E., E. ve Özyamanoğlu, M. (2013). "Finansal Performans ile Kurumsal Yönetim Notları Arasındaki İlişki: BíST Üzerine Bir Uygulama". Akademik Araştırmalar ve Çalışmalar Dergisi, 5(9), 100-117.

Ergül, N.(2014), "BIST Turizm Sektöründeki Şirketlerin Finansal Performans Analizi”, Çankırı Karatekin Üniversitesi İktisadi ve İdari Bilimler Fakültesi Dergisi, 4 (1), 325- 340.

Ertuğrul, İ. ve Özçil, A. (2014). Çok Kriterli Karar Vermede TOPSIS ve VIKOR Yöntemleriyle Klima Seçimi. Çankırı Karatekin Üniversitesi İktisadi ve İdari Bilimler Fakültesi Dergisi, 4(1), 267- 282. 
http://www.otobus.istanbul/dokumanlar/mali-tablolar.aspx (Erişim Tarihi: 11.10.2019)

İç, Y. T., Tekin, M., Pamukoğlu, F. Z. ve Yıldırım, E. (2015), "Kurumsal Firmalar İçin bir Finansal Performans Karşılaştırma Modelinin Geliştirilmesi”, Gazi Üniversitesi MühendislikMimarlık Fakültesi Dergisi, 30 (1), 71- 85.

Kahraman, R. (2009). İşletmelerde Performans Ölçümünün Önemi ve Modern Bir Performans Ölçme Aracı Olarak Balanced Scorecard. Sosyal Ekonomik Araştırmalar Dergisi, 8 (16), 410-427.

Kıngır, S., Karakaş, A. \& Öztel, A. (2016). Evaluatıon Of Unıversıty Employees’ Work Behavıours Performance Via Entropy Based TOPSIS Methods. Elektronik Sosyal Bilimler Dergisi, 15 (58), 1046-1058.

Kiraci, K. ve Bakir, M. (2019). "CRITIC Temelli EDAS Yöntemi ile Havayolu İşletmelerinde Performans Ölçümü Uygulamasi”. Pamukkale Üniversitesi Sosyal Bilimler Enstitüsü Dergisi, (35), 157-174.

Konuşkan, Ö. ve Uygun, Ö. (2014). "Çok Nitelikli Karar Verme (MAUT) Yöntemi ve Bir Uygulamas1”, ISITES2014 Karabük, 1403-1412.

Kung, J. Y., Chuang, T. N. ve Ky, C. M. (2011). "A Fuzzy MCDM Method to Select the Best Company Based on Financial Report Analysis", IEEE International Conference on Fuzzy Systems, 27-30 June, 2011, Taipei, Taiwan, 2013-2017.

Okay Örerler, E. (2005). "Finansal Değerlendirme Açısından Finansal Tabloların Şeffaflığı", Muhasebe ve Denetime Bakış, (15), 2005:1-8.

Orhan, M. (2019). Türkiye ile Avrupa Birliği Ülkelerinin Lojistik Performanslarının Entropi Ağırlıklı EDAS Yöntemiyle Karşılaştırılması. Avrupa Bilim ve Teknoloji Dergisi, (17), 1222-1238.

Ömürbek, N. ve Karataş, T. (2018). Girişimci Ve Yenilikçi Üniversitelerin Performanslarının Çok Kriterli Karar Verme Teknikleri ile Değerlendirilmesi. Mehmet Akif Ersoy Üniversitesi Sosyal Bilimler Enstitüsü Dergisi, 10(24), ss.176-198

Ömürbek, V. ve Kınay, B. (2013). Havayolu Taşımacılığı Sektöründe TOPSIS Yöntemiyle Finansal Performans Değerlendirmesi. Süleyman Demirel Üniversitesi İktisadi ve İdari Bilimler Fakültesi Dergisi, 18(3): 343-36.

Özçelik, H. ve Kandemir, B. (2015). "BIST’de İşlem Gören Turizm İşletmelerinin TOPSIS Yöntemi İle Finansal Performanslarının Değerlendirilmesi”. Ballkesir University The Journal of Social Sciences Institute, 18(33), 97-114.

Perçin, S. ve Sönmez, Ö. (2018). Bütünleşik ENTROPİ Ağırlık ve TOPSIS Yöntemleri Kullanılarak Türk Sigorta Şirketlerinin Performansının Ölçülmesi, Uluslararası İktisadi ve İdari Incelemeler Dergisi, (18. EYİ Özel Say1s1):565-582.

Rençber, Ö. F. (2019). Gri İlişkisel Analiz ve VIKOR Yöntemlerinin Karşılaştırılması: İmalat Sektörü Üzerine Örnek Bir Uygulama. Journal of Yaşar University, 14 (Special Issue), 6981.

Rençber, Ö. F. ve Avcı, T. (2018). BIST'te İşlem Gören Bankaların Sermaye Yeterliliklerine Göre Karşılaştırılması: WASPAS Yöntemi ile Uygulama. Anemon Muş Alparslan Üniversitesi Sosyal Bilimler Dergisi, 6 (ICEESS' 18), 169-175. 
Seçme N.Y., Bayrakdaroğlu, A. ve Kahraman, C. (2009). "Fuzzy Performance Evaluation in Turkish Banking Sector using Analytic Hierarchy Process and TOPSIS", Expert Systems with Applications, 36(9), 11699-11709.

Şenol, Z. ve Ulutaş, A. (2018). "Muhasebe Temelli Performans Ölçümleri ile Piyasa Temelli Performans Ölçümlerinin CRITIC ve ARAS Yöntemleriyle Değerlendirilmesi ”. Finans Politik \& Ekonomik Yorumlar, 55(641), 83-102.

Tayyar, N., Akcanlı, F., Genç, E. ve Erem Ceylan, I. (2014). 'BİST’e Kayıtlı Bilişim ve Teknoloji Alanında Faaliyet Gösteren İşletmelerin Finansal Performanslarının Analitik Hiyerarşi Prosesi (AHP) ve Gri İlişkisel Analiz (GIA) Yöntemiyle Değerlendirilmesi”. Muhasebe ve Finansman Dergisi, Ocak/2014, 19-40.

Tayyar, N., Akcanlı, F., Genç, E., Erem Ceylan, I. (2014). "BİST’e Kayıtlı Bilişim ve Teknoloji Alanında Faaliyet Gösteren İşletmelerin Finansal Performanslarının Analitik Hiyerarşi Prosesi (AHP) ve Gri İlişkisel Analiz (GİA) Yöntemiyle Değerlendirilmesi”. Muhasebe ve Finansman Dergisi, Ocak/2014, 19-40.

Tufan, C. ve Kılıç, Y. (2019). Borsa İstanbul'da İşlem Gören Lojistik İşletmelerinin Finansal Performanslarinin TOPSIS ve VIKOR Yöntemleriyle Değerlendirilmesi. Cumhuriyet Üniversitesi İktisadi ve İdari Bilimler Dergisi, 20 (1), 119-137.

Ünlü, U., Yalçın, N. ve Yağlı, İ. (2017). "Kurumsal Yönetim Ve Firma Performansı: TOPSIS Yöntemi ile BIST-30 Firmaları Üzerine Bir Uygulama". Dokuz Eylül Üniversitesi Sosyal Bilimler Enstitüsü Dergisi, 19(1), 63-81.

Wang, Y. J. (2008), "Applying FMCDM to Evaluate Financial Performance of Domestic Airlines in Taiwan", Expert Systems with Applications, 34(3), 1837-1845.

Yükçü, S. (2004), Finansal Muhasebe, İzmir: Birleşik Matbaacılık. - Kayıt Dışı Ekonomi Özel İhtisas Komisyonu Raporu, (2001), Sekizinci Beş Yıllık Kalkınma Planı, DPT, 2001.

Zietsman J., Rilett L. R. ve Kim S. J. (2006). "Transportation Corridor Decision Making With Multi Attribute Utility Theory", Int. J. Management And Decision Making, 7(2/3): 254-266. 